\title{
PEMBERDAYAAN IBU-IBU PKK DALAM PELATIHAN PEMBUATAN DECOUPAGE BERBASIS INDUSTRI KREATIF
}

\author{
Nidya Wisudawati ${ }^{1}$ * \\ Fakultas Teknik, Universitas Muhammadiyah Palembang \\ email: nidyawisudawati@gmail.com \\ Marhaini $^{2}$ \\ Fakultas Teknik, Universitas Muhammadiyah Palembang \\ email : marhainiump@gmail.com \\ Mardwita $^{3}$ \\ Fakultas Teknik, Universitas Muhammadiyah Palembang \\ email : wiiwtdiita@gmail.com \\ Rurry Patradhiani ${ }^{4}$ \\ Fakultas Teknik, Universitas Muhammadiyah Palembang \\ email : patradh24@gmail.com \\ Merisha Hastarina ${ }^{5}$ \\ Fakultas Teknik, Universitas Muhammadiyah Palembang \\ email : icha3005@gmail.com
}

\begin{abstract}
ABSTRAK
Pelatihan ini bertujuan untuk meningkatkan kemandirian ekonomi ibu Rumah Tangga di RT 030 RW 007 Kelurahan Kalidoni Palembang. Pelaksanaan kegiatan ini dikemas secara interaktif dengan menghadirkan narasumber dosen Fakultas Teknik Universitas Muhammadiyah Palembang. Bentuk kegiatan pengabdian berupa pelatihan teknik Decoupage, teknik ini adalah teknik memperindah barang yang biasa menjadi produk yang bagus, bernilai seni dan bernilai jual lebih tinggi. Bahan yang digunakan berupa bahan tas anyaman polos yang kemudian dengan teknik decoupage (dari bahasa Perancis yang artinya memotong, mendekorasi), ditempel dengan kertas tisu motif (napkin) dilanjutkan dengan di varnish, akan menghasilkan tas anyaman yang indah. Keterampilan ini cukup mudah tapi membutuhkan ketelitian dan kelembutan karena kertas tisu yang digunakan sangat halus dan mudah robek jika kurang hati-hati dalam memotong, menempel dan memvarnish. Tidak hanya sekedar pelatihan tetapi dalam kegiatan ini juga diadakan penyuluhan berbisnis online melalui marketplace dan media sosial. Sebuah solusi yang efektif bagi ibu usia produktif namun tidak bekerja diluar rumah. Secara keseluruhan pelaksanaan kegiatan dapat memberikan peluang usaha baru bagi Ibu Rumah Tangga.
\end{abstract}

Kata Kunci: Decoupage, industri kreatif, marketplace, Palembang, strategi marketing.

\footnotetext{
* Koresponden
} 


\section{ABSTRAK}

This training aims to increase the economic independence of housewives in RT $030 \mathrm{RW} 007$, Kalidoni Village, Palembang. The implementation of this activity is packaged interactively by presenting lecturers from the Faculty of Engineering, University of Muhammadiyah Palembang. The form of service activities is in the form of decoupage technique training, this technique is a technique of beautifying ordinary items into good products, artistic value and higher selling value. The material used is plain woven bag material which is then decoupage technique (from French which means cutting, decorating), affixed with motif tissue paper (napkin) followed by varnishing, will produce a beautiful woven bag. This skill is quite easy but requires precision and gentleness because the tissue paper used is very smooth and easily torn if you are not careful in cutting, pasting and varnishing. Not only training, but in this activity, online business counseling is also held through the marketplace and social media. An effective solution for mothers of productive age but do not work outside the home. Overall, the implementation of activities can provide new business opportunities for housewives.

Keywords: Decoupage, creative industry, marketplace, Palembang, marketing strategy

\section{PENDAHULUAN}

Decoupage memiliki sejarah panjang dan menarik selama berabad-abad. Sejumlah tokoh ternama seperti Marie Antoinette, Madame de Pompadour, Lord Byron, Beau Brummel hingga Picasso pernah mempraktikkan seni yang namanya diambil dari bahasa Prancis découper itu [1]. Pada abad ke-12, para petani Cina menggunting kertas warna-warni dan menempelkannya untuk menghias jendela, lentera, kotak hadiah dan benda lainnya. Namun praktik decoupage ini diduga berasal dari Siberia Timur, di mana banyak makam di sana dihias dengan seni gaya decoupage ini. Selain itu para pengrajin Jerman dan Polandia juga telah menggunakan seni potongan kertas ini untuk melakukan dekorasi selama beberapa abad. Perempuan dan anak-anak di Polandia khususnya, mengembangkan keterampilan melipat kertas berwarna dan memotongnya menjadi bentuk geografis, burung, hewan hingga bunga-bungaan sebelum menempelnya pada media tertentu. Pada akhir abad 17, di Timur Jauh, sebagian besar furniturnya dihias dengan seni decoupage. Banyaknya permintaan akan benda pernis oriental di Eropa membuat kabinet Venetian menghasilkan karya palsu dengan teknik decoupage ini untuk memenuhi permintaan [2].
Perkembangan industri kreatif di Indonesia sudah semakin berkembang pesat itu sudah terlihat dari beberapa daerah di indonesia. Tentu ini menjadikan industri kreatif sangat berpotensi bisa berkembang di Indonesia. Ekspor industri kreatif di indonesia mengalami peningkatan setiap tahunnya. Berikut merupakan hal yang melatarbelakangi perkembangan industri kreatif yang ada yaitu sebagai berikut [3] [4]:

\section{- Kreativitas}

Dalam dunia industri kreatif tentu harus memiliki kreatifitas yang tinggi. karena pelaku industri kreatif kebanyakan anak muda sehingga kreatifitas dan potensi mereka tanpa batas. Sehingga bisa membantu mendorong perkembangan industri kreatif di indonesia.

- Kemajuan Teknologi

Kemajuan teknologi sangat mempengaruhi industri kreatif tanah air. Seperti yang kita tahu kecanggihan teknologi sudah menjadi pendukung bagi pelaku industri kreatif menengah.

- Media sosial

Tidak bisa dipungkiri lagi peran media sosial sangat memberikan potensi besar bagi pelaku bisnis tak terkecuali pelaku industri kreatif. Karena bisa menawarkan barang untuk di jual melalui media sosial, sehingga ikut membantu dalam perkembangan 
- Marketplace

Perdagangan elektronik atau yang biasa dikenal marketplace adalah kegiatan jual beli barang/jasa atau transmisi dana/data melalui jaringan elektronik, terutama internet.

\section{IDENTIFIKASI MASALAH}

PkM ini akan dilaksanakan di Kecamatan Kalidoni Kelurahan Kalidoni RT. 30 RW. 07 Lorong Saudara 3, Palembang. Peserta pengabdian merupakan ibu - ibu PKK yang berjumlah kurang lebih 20 orang. Rata - rata usia peserta 30 - 40 tahun dan hanya beberapa yang berusia $20-30$ tahun. Usia ini tergolong masih produktif, sedangkan tak satu orang pun yang menjadi ibu pekerja. Potensi lain juga dapat dilihat dari kemampuan ibu - ibu ini mengoperasikan gadget yang juga dapat berfungsi sebagai media untuk berbisnis online. Oleh karena itu, pelatihan keterampilan decoupage kepada ibu -ibu tersebut dapat berkembang menjadi lapangan kerja yang menghasilkan dengan metode pemasaran yang memanfaatkan marketplace dan media sosial [5] [6].

\section{METODOLOGI PELAKSANAAN}

Metode pelaksanaan dibagi dalam beberapa tahap, yaitu:

1) Tahap persiapan

Tahap persiapan kegiatan dilaksanakan dengan berkoordinasi dengan mitra dalam hal ini RT. 30 Kelurahan Kalidoni untuk menentukan waktu kegiatan dan kegiatan yang akan dilaksanakan. Kegiatan PkM ini ditujukan bagi ibu rumah tangga yang belum memiliki penghasilan tambahan. Lokasi kegiatan berada di kediaman ketua RT. Narasumber kegiatan adalah tim dosen Fakultas Teknik Universitas Muhammadiyah Palembang yang sekaligus akan menyediakan alat dan bahan yang diperlukan.

2) Pelatihan pembuatan kerajinan decoupage Langkah selanjutnya adalah salah satu rangkaian dari pelaksanaan PkM. Kegiatan ini dilakukan selama satu hari.
Sesi pertamanya adalah pelatihan pembuatan kerajinan decoupage. Diawali dengan pemberian materi melalui slide show, maka diharapkan seluruh peserta mengetahui gambaran apa itu decoupage, apa saja yang bisa dijadikan kerajinan decoupage serta alat dan bahan yang digunakan. Kegiatan dilanjutkan dengan praktik langsung pembuatan kerajinan decoupage dari dompet berbahan pandan. Step by step pembuatan dipraktekkan secara runtut dengan langsung dipraktekkan juga oleh masing-masing peserta sehingga tujuan pelaksanaan kegiatan PkM yang berusaha menjawab permasalahan mitra dengan memberikan pembekalan ide bisnis kewirausahaan tercapai.

3) Penyuluhan kewirausahaan.

Tahap akhir dari kegiatan ini adalah sesi lanjutan dari sesi sebelumnya. Penyuluhan mengenai pemanfaatan media sosial dan marketplace sebagai wadah untuk berwirausaha. Pengenalan marketplace Shopee sebagai situs elektronik komersial yang dapat dijadikan lapak untuk menjual kerajinan decoupage diberikan kepada peserta. Langkah pembuatan akun hingga mengelola akun sebagai penjual langsung dipraktekkan pada gadget peserta masingmasing. Hal ini juga menjawab permasalahan mitra untuk memberdayakan sebagian besar warganya yang merupakan ibu rumah tangga.

\section{HASIL DAN PEMBAHASAN}

Pelaksanaan Pengabdian Kepada Masyarakat (PKM) dilakukan di Lorong Keluarga 3, bertempat dikediaman Ketua RT. 030 Kelurahan Kalidoni Kecamatan Kalidoni Palembang yang telah berjalan dengan baik dan lancar. Acara dimulai sejak pukul 14.00 WIB pada tanggal 23 Januari 2020 yang dihadiri oleh 20 peserta. Peserta kegiatan ini merupakan ibu rumah tangga yang juga ibu PKK kelurahan Kalidoni yang kesehariannya hanya beraktifitas di rumah. Mereka merupakan kelompok ibu - ibu usia produktif yang kesemuanya memiliki smartphone sebagai kunci utama dalam kegiatan ini. 


\section{Sesi Pelatihan Pembuatan Decoupage}

Acara dimulai dengan sambutan dari Ibu RT 030 yang sekaligus menjadi tuan rumah dalam kegiatan ini. Semua peserta kegiatan dapat mengikuti acara dari awal hingga akhir acara dengan seksama. Penyampaian menggunakan bahasa yang ringan dan mudah dimengerti membuat semua peserta kegiatan tidak mengalami kesulitan dalam mengikuti rangkaian acara. Acara dilanjutkan dengan membuat sendiri kerajinan seni decoupage oleh masing - masing peserta yang sebelumnya telah diberikan alat dan bahan yang dibutuhkan.

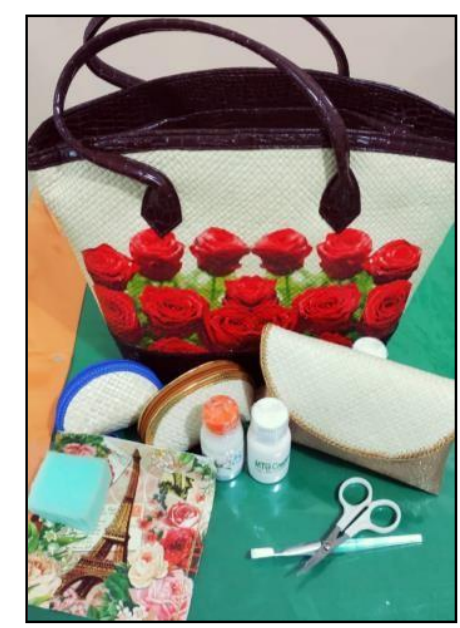

Gambar 1. Alat dan Bahan

Kerajinan inilah yang akan menjadi produk siap jual kemudiannya. Ibu - ibu berlatih mengembangkan diri dengan menambah keterampilan mereka. Decoupage sendiri bukanlah hal yang sulit karena dapat dikerjakan oleh siapapun tanpa terikat waktu. Pemakaian bahan yang mudah didapat dan dengan unsur etnik serta up to date ini mampu menarik perhatian para peserta [7]. Kebutuhan para ibu akan kebutuhan pangan berupa tas/ dompet yang unik dan up to date membuat kegiatan ini langsung mendapatkan respon positif oleh seluruh peserta. Dari hasil wawancara menyatakan bahwa kegiatan pelatihan kerajinan decoupage ini belum pernah diadakan sebelumnya di daerah ini.

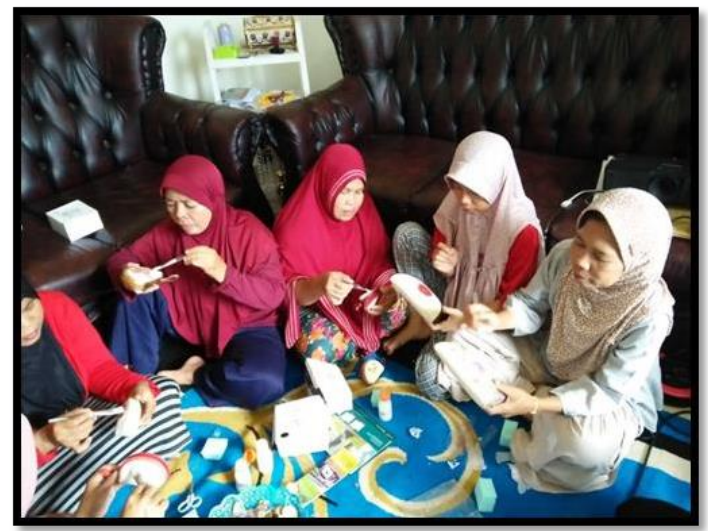

Gambar 2. Suasana Kegiatan

\section{Sesi Penyuluhan Kewirausahaan}

Sesi dilanjutkan dengan pemaparan tahapan dalam membuat akun di marketplace seperti Shopee.

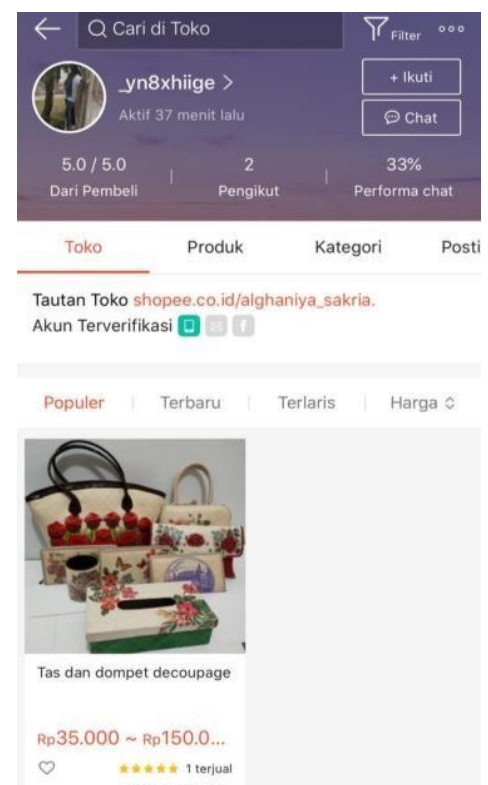

\section{Gambar 3. Contoh Akun Shopee Peserta}

Beberapa pertanyaan dilontarkan oleh peserta terkait bisnis dengan media ini. Hal ini menunjukkan bahwa peserta memiliki antusiasme yang tinggi terhadap kegiatan ini. Sebagian besar dari peserta telah memiliki media sosial berupa whatsapp dan facebook pada smartphone mereka, namun belum ada yang memanfaatkannya untuk memulai bisnis secara online. Ide tambahan berupa menjadi penjual di akun marketplace 
(Shopee) membuat peserta menjadi semakin semangat.

Pada akhir kegiatan, ditutup dengan sesi dokumentasi dan serah terima produk dengan ibu RT beserta seluruh peserta kegiatan.

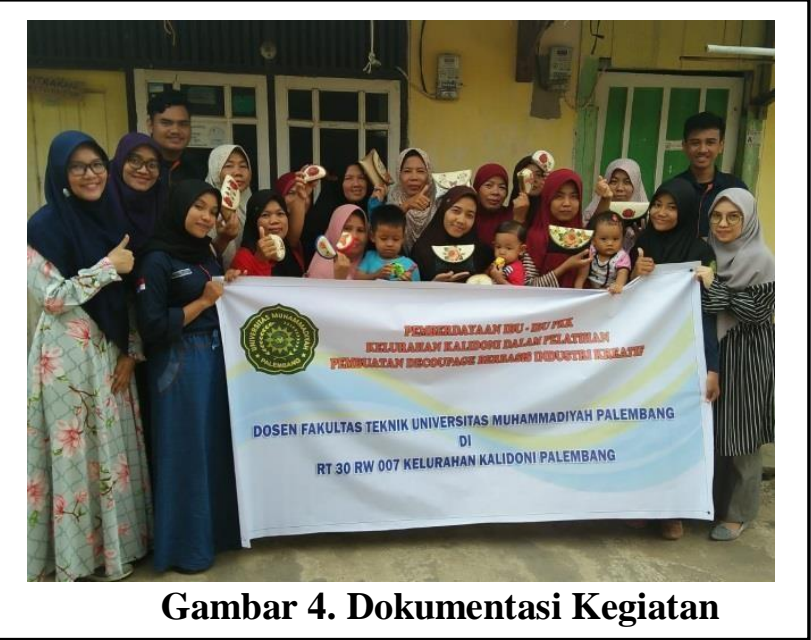

\section{KESIMPULAN}

Berdasarkan kegiatan pengabdian yang telah dilakukan, maka dapat disimpulkan bahwa kegiatan ini memberikan kesempatan pada para ibu rumah tangga yang tidak bekerja untuk dapat memaksimalkan waktu luangnya dengan membuka usaha kerajinan decoupage. Metode pemasaran bisnis secara online melalui marketplace dan media sosial sudah tidak asing di kalangan ibu-ibu, hanya saja selama ini dimanfaatkan sebatas pengguna/ pembeli saja.

\section{UCAPAN TERIMA KASIH}

Tim dosen kegiatan pengabdian kepada masyrakat ini mengucapkan terimakasih kepada Lembaga Penelitian dan Pengabdian Masyarakat (LPPM) Universitas Muhammadiyah yang telah memberikan fasilitas dan pendanaan pada kegiatan ini dalam Hibah Internal Pendanaan Tahun 2019.

\section{REFERENSI}

[1] Republika, "Sejarah Panjang Seni Decoupage," 2019. [Online].

Available:

https://www.republika.co.id/berita/ga ya-hidup/trend/16/11/22/oh0xxq384ini-dia-sejarah-panjang-senidecoupage. [Accessed: 21-May2019].

[2] N. Nurlaila and L. Yulastri, "Pemberdayaan Ibu-Ibu Pkk Kelurahan Rawamangun Dalam Pelatihan Pembuatan Decoupage Dari Tissue Berbasis Industri Kreatif," Sarwahita, vol. 14, no. 02, pp. 151155, 2017, doi:

10.21009/sarwahita.142.10.

[3] N. Nurmaya, N. E. Diana, I. Kurnianingsih, and R. Rosini, "Pelatihan Peningkatan Nilai Produk Kerajinan Tangan Decoupage dan Pemasaran Produk untuk Ibu Rumah Tangga," MATAPPA J. Pengabdi. Kpd. Masy., vol. 2, no. 1, p. 53, 2019, doi: 10.31100/matappa.v2i1.306.

[4] M. Sari, D. Brilianti, and I. Bukhori, "Peningkatan Kreatifitas Ibu-Ibu Pkk Pesurungan Lor Melalui Pemanfaatan Barang Bekas Rumah Tangga Menjadi Produk Decoupage Bernilai Estetikonomis," J. Pengabdi. Masy. Progresif Humanis Brainstorming, vol. 1, no. 2, pp. 105-110, 2018, doi: 10.30591/japhb.v1i2.955.

[5] Agribisnis Online, "Industri Kreatif," 2019. [Online]. Available: https://agribisnis.co.id/industrikreatif/. [Accessed: 21-May-2019].

[6] N. Aini and N. Asma, "Pemberdayaan Ibu-Ibu Pkk Rancabungur Melalui Keterampilan Dan Manajemen Keuangan Usaha Craft Decoupage," Semin. Nas. ADPI Mengabdi Untuk Negeri, vol. 1, no. 1, pp. 142-147, 2020, doi: 10.47841/adpi.v1i1.41.

[7] D. R. Indriastuti and R. F. Ahsani, "Pengembangan Teknik Decoupage Pada Tas Anyaman Bagi Ibu PKK Kelurahan Tegalharjo," in SENADIMAS UNISRI, 2019, no. September, pp. 401-403. 